University of Pennsylvania Carey Law School

Penn Law: Legal Scholarship Repository

Faculty Scholarship at Penn Law

2-11-2011

\title{
Quantification of Harm in Private Antitrust Actions in the United States
}

Herbert J. Hovenkamp

University of Pennsylvania Carey Law School

Follow this and additional works at: https://scholarship.law.upenn.edu/faculty_scholarship

Part of the Antitrust and Trade Regulation Commons, Courts Commons, Economic Policy Commons, Industrial Organization Commons, Law and Economics Commons, Legal Remedies Commons, Litigation Commons, and the Policy Design, Analysis, and Evaluation Commons

\section{Repository Citation}

Hovenkamp, Herbert J., "Quantification of Harm in Private Antitrust Actions in the United States" (2011). Faculty Scholarship at Penn Law. 1860.

https://scholarship.law.upenn.edu/faculty_scholarship/1860

This Article is brought to you for free and open access by Penn Law: Legal Scholarship Repository. It has been accepted for inclusion in Faculty Scholarship at Penn Law by an authorized administrator of Penn Law: Legal Scholarship Repository. For more information, please contact PennlawIR@law.upenn.edu. 


\section{QUANTIFICATION OF HARM IN PRIVATE ANTITRUST ACTIONS IN THE UNITED STATES}

Herbert Hovenkamp*

\section{INTRODUCTION}

This paper briefly discussed the theory and the experience that United States courts and antitrust scholarship have encountered with respect to quantification of harm in antitrust cases. This treatment pertains to both the social cost of antitrust violations, and to the remedial damage mechanisms that United States antitrust law has developed.

In a typical year more than $90 \%$ of antitrust complaints filed in the United States are by private plaintiffs rather than the federal government. ${ }^{1}$ Further, when the individual states in our federal system file their actions under federal antitrust law they are entitled to assert claims for damages as well. ${ }^{2}$ The vast majority of private antitrust actions in the United States include a claim for damages. It is little wonder, because the private damages provision, $\S 4$ of the Clayton Act, grants trebled (threefold) damages, plus attorneys fees to prevailing plaintiffs. Section 4 of the Clayton Act provides in relevant part that:

any person who shall be injured in his business or property by reason of anything forbidden in the antitrust laws may sue therefor in any district court of the United States in the district in which the defendant resides or is found or has an agent, without respect to the amount in controversy, and shall recover threefold the damages by him sustained, and the cost of suit, including a reasonable attorney's fee. ${ }^{3}$

This section has been interpreted by the United States Supreme Court to permit lawsuits by ordinary consumers ${ }^{4}$ as well as business firms, and to require proof of a

\footnotetext{
* Ben V. \& Dorothy Willie Professor of Law, University of Iowa, Iowa City, Iowa, USA. Herberthovenkamp@uiowa.edu; 319-335-9079.

${ }^{1}$ See Sourcebook of Criminal Justice Statistics Online, available at http://www.albany.edu/sourcebook/pdf/t5412006.pdf. (last visited Jan. 25, 2011) The data, which go through 2006 show percentages of private actions from 1995-2006 ranging from 89\% to $96 \%$. The data do not include Federal Trade Commission challenges that never go into a district court.

${ }^{2} 15$ U.S.C. $\$ 15 c$ (2006).

${ }^{3} 15$ U.S.C. $\$ 15$ (2006).

${ }^{4}$ Reiter v. Sonotone Corp., 442 U.S. 330 (1979).
} 
violation plus causation in fact. ${ }^{5}$ It expressly requires that compensation be measured by reference to the plaintiff's losses (damages "by him sustained") rather than by alternative measures that one might view as superior. Under the Seventh Amendment to the United States Constitution all damages actions such as these must go to a jury of laypersons if either party so requests, and the jury's job will be to interpret all admissible expert testimony and compute damages, subject only to judicial control for ignoring instructions or reaching irrational verdicts. Trebling is mandatory and jurors are not instructed about trebling, for fear that they will temper their awards so as to reflect its consequences. ${ }^{6}$ Of course, jurors are laypersons with various degrees of knowledge about the antitrust system, and certainly some of them may know about trebling. ${ }^{7}$ Suffice it to say that the intervention of a jury does not serve to make damages outcomes in U.S. cases more rational.

\section{COMPENSATION vs. DETERENCE}

As noted above, the damages measure authorized by the Clayton Act is based purely on compensation, and Congress has never seriously considered changing it. As it turns out, compensation for losses is rarely the measure that is also sufficient to produce the optimal level of deterrence.

As a basic premise, damages measured with deterrence as a goal should seek to be large enough to deprive an antitrust violator of reasonably anticipated improperly obtained gains plus a little more, adjusted by the probability of detection and prosecution. For example, suppose a cartel sold 1 million units at a cartel overcharge of $10 €$ per unit, and thus earned total profits of 10 million $€$, ignoring all costs of administering the cartel, internal inefficiencies resulting from misdirected output, and the like. ${ }^{8}$ Because that 10 million $€$ gain to cartel members is identical to the overcharge, optimal damages measured ex post would be 10 million $€$ plus a small amount so that the conduct is unprofitable. However, suppose that only one in three cartels is detected and successfully prosecuted. In that case, considered ex ante, the correct rule would be treble damages. That is, the trebled overcharge is the correct rule assuming that the

\footnotetext{
${ }^{5}$ See 2A Phillip E. AREedA AND Herbert HovenKAmP, ANTITRUST LAW TIII337-340 (3d ed. 2007 \& Supp.).

${ }^{6}$ HBE Leasing Corp. v. Frank, 22 F.3d 41, 46 (2d Cir. 1994); Heatransfer Corp. v. Volkswagenwerk, A.G., 553 F.2d 964, 989 ( $5^{\text {th }}$ Cir. 1977).

${ }^{7}$ E.g., Cape Cod Food Prods. V. Nat'l Cranberry Ass'n,, 119 F.Supp. 900 (D.Mass. 1954) (jury instruction to disregard anything they think they might know about trebling)

${ }^{8}$ On the problems and costs of cartel administration, see HERBERT HOVENKAMP, FEDERAL ANTITRUST POLICY: THE LAW OF COMPETITION AND ITS PRACTICE, $\S \S 4.1$ - 4.3 (3d ed. 2011).
} 
probability of detection is one in three. To generalize, the optimal damage award is the overcharge multiplied by the inverse of the probability of detection and successful prosecution. $^{9}$

Some antitrust violations produce efficiencies, or cost savings, even as they injure competition. A good example is mergers, where costs savings can be significant but very difficult to prove. Another is practices such as tying, which may increase welfare just as they are unlawful. ${ }^{10}$ Theoretically we might say that these are cases of incorrect application of antitrust rules. Be that as it may, however, damages must be quantified in any case where damages are deemed appropriate. In such cases the sum of the overcharge plus the monopoly "deadweight loss" is the correct measure to deter. ${ }^{11}$ For example, suppose that a merger produces 3 million $€$ in overcharges but 1 million $€$ in efficiency gains. Assume that the price increase causes not only a 3 million $€$ overcharge, but also a deadweight loss of 2 million $€$, which results from customers who switch to an inferior product in response to the higher post-merger prices. We characterize this as a deadweight loss because the consumers lose by making an inferior choice, but the merger partners also lose because they earn nothing on unmade sales. In this case the optimal penalty is 3 (overcharge) +2 (deadweight loss), or 5 million $€$. Because the merging partners earn 4 million $€$ on the merger ( 3 million in overcharges and 1 million in efficiency savings) the merger is unprofitable and will be deterred.

Suppose, however, that the deadweight loss is only $500,000 €$. In that case the penalty of overcharge plus deadweight loss will be insufficient to deter the merger because the efficiency gains are greater than the deadweight loss imposed by the merger. Everything else is a pure wealth transfer. As a result, the merger will proceed, consistent with the proposition that it is socially beneficial even though it results in some consumer harm. If the principal concern of competition policy were stated as consumer welfare rather than general economic welfare ${ }^{12}$ this would still be the correct measure.

\footnotetext{
${ }^{9}$ See id., $\$ \$ 17.2-17.3$.

${ }^{10}$ Erik Hovenkamp \& Herbert Hovenkamp, Tying Arrangements and Antitrust Harm, 52 ARIZ.L.REV. 924 (2010), available at http://papers.ssrn.com/sol3/papers.cfm?abstract_id=1443284.

${ }^{11}$ See William M. Landes, Optimal Sanctions for Antitrust Violations, 50 U.CHI.L.REV. 652 (1983); Herbert Hovenkamp, Treble Damages Reform, 33 ANTITRUST BULL. 233 (1988).

${ }^{12}$ General welfare is concerned with the welfare of all persons affected, while consumer welfare is concerned only with the welfare of consumers, ignoring that of producers.
} 
The consumers would still recover their losses, but the merger would go forward if the efficiency gains exceeded the deadweight loss. ${ }^{13}$

This optimal deterrence model is not even a close approximation of the reality of damage measures in the United States, and probably for good reason. Several observations about it are possible:

1. Even in the case of a simple naked cartel producing no efficiency gains whatsoever, the overcharge measure produces optimal deterrence only if we have some way of knowing ex ante what the probability of detection and successful prosecution is. Trebled damages under United States law would be about right if the probability of cartel detection were .33. In all probability, however, the detection rate is not higher than .2, making a trebling multiplier too low. ${ }^{14}$ In other cases such as mergers, however, the probability of detection is $100 \%$ because the merger is a public rather than a concealed act. In such cases trebled damages are probably excessive. In sum, trebling damages for all types of violations is not particularly rational, given the great differences in probability of detection.

2. As soon as an antitrust violation has a significant possibility of producing efficiency gains the optimal penalty must include the deadweight loss, assuming that deterrence of practices only to the extent they are inefficient is the appropriate goal. However, measuring deadweight loss in a courtroom is extraordinarily difficult. Theoretically, one could get it by permitting consumers who substitute away from the overpriced product to have a damage action. For example, if in response to a price-increasing merger of two luxury car makers a consumer switched to a third seller's intermediate car, she could recover the loss in consumers' surplus she suffered as a result of the substitution. Such a system would be extremely hard to manage. United States law denies standing to such persons. $^{15}$

\footnotetext{
${ }^{13}$ See Herbert Hovenkamp, Antitrust and the Costs of Movement, ANTITRUST LAW JOURNAL (forthcoming, 2011), available at http://papers.ssrn.com/sol3/papers.cfm?abstract id=1679849.

${ }^{14}$ Michal S. Gal, Free Movement of Judgments: Increasing Deterrence of International Cartels through Jurisdictional Reliance, 51 VA.J.INT'L L. 57 (2010). The European Commission has estimated detection rates as in the range of 10 to 20 percent. See Commission Staff Working Paper accompanying the White Paper on Damages Actions for Breach of the EC Antitrust Rules, at 22, SEC (2008) 404 (Apr. 2, 2008), available at http:// ec.europa.eu/competition/antitrust/actionsdamages/files_white_paper/working_ paper.pdf.

${ }^{15}$ Montreal Trading, Inc. v. AMAX, Inc., 661 F.2d 864 (10th Cir. 1981), cert. denied, 455 U.S. 1001 (1982) (nonpurchaser who substituted away in response to price increase lacked standing to sue).
} 
3. The optimal deterrence model moves even further away from reality when the plaintiff is a competitor rather than a consumer and the measure of damages is lost profits or lost opportunity to do business. Competitor losses depend on such things as the technology in an industry, the nature of the offense, whether the competitor was well established and driven out of business, whether its plant and equipment could be resold or had to be destroyed or sold for salvage, whether the competitor lost and will be entitled to recover future, unmade profits, to name a few. Once computed, this number could be either far greater or far smaller than the optimal amount of deterrence. For example, in a predatory pricing case that ruins a rival and results in a sustained period of higher prices, deterrence would be accomplished by capturing the net gains to the predator. This number has no quantifiable relationship to the value of the rival's lost business.

4. The overcharge plus deadweight loss methodology does not pick up the true social cost of anticompetitive behavior to the extent that unlawful acts cause harm that is not reflected in product pricing and output decisions. Most notably, the social cost includes not only the monopoly deadweight lost but also any lost investment or productivity by actual or potential rivals. For example, suppose a dominant firm files an improper patent infringement suit in order to retain its monopoly position. The social cost is not only the effects resulting from extension of the dominant firm's monopoly but also the rival's lost investment plus the value of any superior technology that might be deterred or prevented by the anticompetitive act. $^{16}$

\section{OVERCHARGE INJURIES AND PASSING-ON}

An intuitively stronger relationship exists between optimal deterrence and compensation that is based on an overcharge, as opposed to compensation based on the lost profits of excluded rivals. Overcharge measures are injuries that are suffered by consumers, both direct and indirect. Theoretically they are superior for achieving optimal deterrence regardless of the identity of the plaintiff. As a result, one might conceive of a system in which the plaintiff was an excluded rival (challenging predatory pricing, improper enforcement of IPRs, etc) but the damages were based on the overcharge. In effect, rivals would be suing but they would be collecting someone else's damages, namely those suffered by consumers. In any event, the U.S. Clayton Act would not permit such a measure and it seems to conflict with a basic tort premise that injured plaintiffs are entitled to their own damages.

\footnotetext{
${ }^{16}$ See HovenKAMP, FEDERAL ANTITRUST POLICY, supra, $\S 1.3 \mathrm{~d}\left(4^{\text {th }} \mathrm{ed} .2011\right)$; ChristinA BoHANNAN AND HERBERT HOVENKAMP, CREATION WITHOUT RESTRAINT: PROMOTING LIBERTY AND RIVALRY IN INNOVATION, chs. 2-3 (N.Y. \& London: Oxford Univ. Press, 2011, forthcoming).
} 
The most interesting issues respecting overcharge damages are (1) methodologies of measurement, and (2) passing on problems.

\section{Methodologies of Measurement}

In United States antitrust law the most common methods of measurement seek to compare the market in which the violation occurred with some alternative market (in space, time, or product) that was free of the antitrust violation. For example, the socalled "yardstick" method compares prices, performance, or some other index of harm in the violation market with the same variable in some alternative, or "yardstick" market that is assumed to be performing competitively. To illustrate, if liquor sellers in one Texas city are engaged in price fixing, one might measure damages by comparing prices in this city during the cartel period with prices in a reasonably similar city where price fixing is assumed not to be occurring. ${ }^{17}$ By contrast, the "before and after" method looks exclusively at the violation market, but tries to compare prices, output, or some other index from the period prior to or subsequent to the violation period (or preferably both). For example, if a cartel formed July 1, 2007 and dissolved July 1, 2010, one might compare prices during the cartel period with prices immediately before the cartel was formed or immediately after it fell apart. ${ }^{18}$

Both methods have become technically quite demanding and typically require the use of an expert trained in the use of statistics. Even in the hands of a qualified expert, both suffer from severe limitations depending on the circumstances. For example, two yardstick markets are not likely to have entirely identical cost structures, wage rates, and the like. As a result, adjustments will have to be made. Further, often a cartel operates to "stabilize" prices without really increasing prevailing prices; as a result, the before and after method might understate harm. In addition, exogenous factors such as mergers, changes in technology, the overall health of the economy can all affect these measures. Over the years economists and statisticians have developed control techniques to deal with these problems or others, but no one believes that the methodologies provide more than a rough approximation of reality.

\section{Passing On Problems}

Most but not all cartels sell to various intermediaries rather than end users. Further, the price-fixed product is often only one component of a finished product, and the effect of the fix may pass down through a distribution chain in complex ways. For

\footnotetext{
${ }^{17}$ E.g., Greenhaw v. Lubbock County Beverage Assn., 721 F.2d $1019\left(5^{\text {th }}\right.$ Cir. 1983) (employing yardstick method). On use of the methodology by experts, see 2A PHILliP E. AREEDA, HERBERT HovenKAMP, Roger D. Blair, AND Christine PietTe DuRRANCE, ANTITRUST LAW II395 (3d ed. 2007).

${ }^{18}$ Id., $\Phi[395$.
} 
example, in the infamous vitamin cartel case the product whose price was fixed was vitamins administered to cattle and other livestock. ${ }^{19}$ Depending on the particular vitamin and the market situation, these price-fixed vitamins could be sold to a distributor who resold them in the same form to a feed mill. The feed mill then mixed the vitamins into cattle feed which it sold perhaps to a second level distributor and then to a dealer. Farmers then purchased the feed containing the cartelized vitamins. The effect was to increase farmers' costs and thus they charged more for the beef or milk that they produced. This beef or milk was then sold to distributors or retail grocers, who then sold them to consumers. Very likely these price fixed vitamins passed through a half dozen or more intermediaries before the higher price came to rest with end users. The degree of pass-on depends on a variety of factors, including whether the proportions of the price-fixed product can be varied and whether the priced fixed good is a fixed cost or variable cost item in an intermediary's operations.

Not all distribution chains are this complex. When passing on occurs, however, it is likely that most of the overcharge is passed on, while some smaller amount is retained by each person in the distribution chain. For example, a large grocer might routinely follow a formula in which it adds $10 \%$ to the wholesale price that it pays when selling the product at retail. Indeed, in this particular case the intermediary actually makes more money on the marked up product. For example, if the noncartel wholesale price was $30 €$ the retail price would be $33 €$. However, if the cartel increases the wholesale price to $40 €$ the retail price would be $44 €$ and the retailer would earn a profit of $4 €$ rather than $3 €$. More generally, the impact of the price increase is to reduce sales, and ordinarily an intermediary responds to reduced demand by reducing its markup (although high fixed costs may prevent this). So about the best general conclusion one can draw is that intermediaries typically absorb some relatively small portion of the overcharge, sometimes ranging down to zero, while the larger portion of the overcharge rests with customers.

Note also that there are some severe qualifiers to this general observation. Most significantly, if the cartel and the intermediary operate in different size markets passing on may be impossible. For example, suppose that a local cartel of gasoline retailers fixes prices, something they can do because gasoline is costly to transport. The price fixed gasoline is then sold to farmers who grow wheat and sell it in a worldwide market. In this case the farmers will very likely absorb the entire loss that results from the price

${ }^{19}$ F. Hoffman-La Roche Ltd. v. Empagran S.A., 542 U.S. 155 (2004). For some of the problems, see Hans W. Friederiszick and Lars-Hendrik Roller, Quantification of Harm in Damages Actions for Antitrust Infringements: Insights from German Cartel Cases, 6 J.COMPETITION L. \& ECON. 595 (2010); Victor P. Goldbert, The Empagran Exception: Between Illinois Brick and a Hard Place, 2009 COLUMBIA L.REV. 785 (2009). 
fix because they are purchasing in a cartelized market but reselling in a competitive market. So nothing will be passed on. A similar result can occur when the cartelized good is a fixed cost to the intermediary. For example, the construction brick that was the subject of price-fixing in the Illinois Brick case would be a variable cost to the pricefixers and to contractors who used the brick in construction projects, but it would be a fixed cost item to a factory owner who built a durable production facility with the brick. Fixed costs are typically not passed on at all, or else they are accounted for only indirectly in ways that have little to do with actual incremental costs. For example, it is very difficult to say how an overcharge in bricks used to build a commercial bakery would show up in the way that the baker priced its bread.

In sum, not only are passing on problems very complex, they are also quite specific to the situation. In some cases everything is passed on. In other cases nothing is.

Today United States antitrust law on this issue is in a turbulent state. In the Illinois Brick decision, now 35 years old, the Supreme Court held that under federal antitrust law direct purchasers are entitled to obtain the entire overcharge as damages, without any reduction for damages that were passed on rather than absorbed. ${ }^{20}$ As a consequence, indirect purchasers were not entitled to obtain anything, except in a few narrowly defined circumstances. ${ }^{21}$ In subsequent years, however, the Supreme Court also permitted state antitrust laws to deviate by recognizing indirect purchaser claims. ${ }^{22}$ As of now roughly half of the states, including very large ones such as California, recognize indirect purchaser claims. This has created a very cumbersome situation in which these claims must be coordinated and the possibility of excessive damages must be recognized. ${ }^{23}$

The Illinois Brick rule was based on two premises, both of which today seem quite questionable. The first premise was that the need to measure passing on by using incidence and shifting theory, as typically involved in tax policy, made quantification of pass on extraordinarily difficult. The second was that concentrating all of the damages

\footnotetext{
${ }^{20}$ Illinois Brick Co. v. Illinois, 431 U.S. 720 (1977). See also Kansas \& Missouri v. Utilicorp United, Inc., 497 U.S. 199 (1990) (applying indirect purchaser rule to public utility that passed on entire monopoly overcharge).

${ }^{21}$ These are spelled out in 3A AREEDA \& HOVENKAMP, ANTITRUST LAW qI346.

${ }^{22}$ California v. ARC America Corp., 490 U.S. 93 (1989).

${ }^{23}$ Most recently, see Clayworth v. Pfizer, Inc., 49 Cal. ${ }^{\text {th }} 758,233$ P.3d 1066 (Cal. 2010), a California Supreme Court decision holding that the direct purchaser's recovery should not be reduced by the amount it passed on, at least in circumstances where the absent indirect purchasers no longer had the right to sue.
} 
into a single level rather than having damages sliced up into numerous pieces would increase incentives to enforce. ${ }^{24}$

On the first premise, technical measurement of passing on of a fee, tax or overcharge depends on the elasticity of supply and demand faced by each individual intermediary. These methodologies can provide useful information about how a tax, such as a sales tax or VAT, is passed on from one business to another in a distribution chain. However, this theory is very difficult to use in litigation. But the prevailing methodologies used in antitrust litigation, the aforementioned "yardstick" and "before and after" methods, do not necessarily require computation of these elasticities at all, but simply comparative observations of pricing in two different markets or two different time periods. ${ }^{25}$

On the second premise, while it is true that the indirect purchaser rule concentrates the entire damages action in the direct purchaser, the first purchaser often has a business relationship with the defendant that makes it an unlikely plaintiff. Indirect purchasers rarely face such concerns. Further, the availability of class actions or, in some cases, assignment, can serve to mitigate coordination problems by concentrating numerous damage claims into a single suitor. ${ }^{26}$

Clearly, however, the system currently in place in the United States, in which direct purchaser claims are lodged mainly in the federal courts under federal law, and indirect purchaser claims are brought under state law, is cumbersome and irrational. A better system would consolidate all purchasers who are injured into a single forum and proceeding for purposes of allocating damages. In sum, any solution to the pass on problem should be "comprehensive," in the sense that it forces all injured parties and the defendant(s) into a common proceeding.

The following more fundamental conclusions can also be drawn:

1. When the purchaser from a cartel or unlawful monopolist is an intermediary the "overcharge" is rarely the correct measure of that purchaser's lost. As noted previously, in the typical situation intermediaries pass on most or sometimes

\footnotetext{
${ }^{24}$ See William Landes \& Richard A. Posner, Should Indirect Purchasers Have Standing to Sue Under the Antitrust Laws? An Economic Analysis of the Rule of Illinois Brick, 46 U. CHI. L. REV. 602 (1979); William Landes \& Richard A. Posner, The Economics of Passing On: A Reply to Harris and Sullivan, 128 U. PA. L. REV. 1274, 1275-1276 (1980); Jeffrey Harris \& Lawrence A. Sullivan, Passing on the Monopoly Overcharge: A Comprehensive Policy Analysis, 128 U. PA. L. REV. 269 (1979).

${ }^{25}$ See 3A Areeda And Hovenkamp, Antitrust LaW, $₫ 346 \mathrm{k}$.

${ }^{26}$ See id., $\llbracket 331$ (class actions), $\uparrow 362$ (assignment).
} 
even all of the overcharge. The real source of injury to intermediaries is lost sales volume. For example, an intermediary that routinely uses formula markups will typically pass on the entire overcharge, but because the cartel restricts output it will experience a loss in sales volume. Its real injury in such cases consists of lost profits from these unmade sales. The end user, by contrast, absorbs the full brunt of the overcharge because it has nothing to pass on. Even in this case the "overcharge" is not the full measure of the end user's harm. End users are also injured because they purchase fewer units of the cartelized good and may substitute to a good that they would have regarded as inferior if the market had been competitive.

2. Apropos of this, a superior method of assessing compensation in a cartel case with multi-layer distribution would be (1) the passed on overcharge to the end user consumer; and (2) lost profits to each intermediary in the distribution chain. The latter measure would include both absorption of loss on markup and also losses resulting from reduced volume.

To illustrate: prior to the cartel a retailer intermediary took a markup of $10 €$ per unit and sold 1000 units. During the cartel period the retailer responded to increased pressure by cutting its markup to $9 €$ and selling 800 units. Its damage in that case would be $1 €$ per unit on the 800 units that it sold, plus lost profits on the 200 unsold units. This would consist primarily of gross margins on the unsold units, less selling expenses.

\section{Conclusion}

United States antitrust law has developed a rich and full record of experience with private antitrust remedies. In the process it has also made serious mistakes that should be avoided. Some of these mistakes are the consequence of a federal system that often forces division of private enforcement prerogatives among different jurisdictions that use inconsistent approaches. Others are simple mistakes of conception or measurement that are often difficult to reverse once they have been established. This makes United States experience a fruitful ground for study. 